\title{
The Immatures of Culicoides trilineatus (Diptera: Ceratopogonidae) Potential Vector of the Bluetongue Virus
}

\author{
F. Diaz, ${ }^{1,8}$ C. Mangudo, ${ }^{2,3}$ G. R. Spinelli, ${ }^{4,5}$ R. M. Gleiser, ${ }^{6,7}$ and M. M. Ronderos ${ }^{1}$
}

'Centro de Estudios Parasitológicos y de Vectores (CEPAVE), Facultad de Ciencias Naturales y Museo (UNLP), Consejo Nacional de Investigaciones Científicas y Técnicas (CONICET), Boulevard 120 S/N e/61 y 62 La Plata, Buenos Aires, Argentina, ${ }^{2}$ Instituto de Investigaciones en Energía No Convencional (INENCO, UNSa- CONICET), Universidad Nacional de Salta, Salta, Argentina, ${ }^{3}$ Instituto de Investigaciones en Enfermedades Tropicales, Sede Regional Orán, Universidad Nacional de Salta, Salta, Argentina, ${ }^{4}$ Instituto de Limnología ‘Dr. Raúl A. Ringuelet' (ILPLA), Facultad de Ciencias Naturales y Museo (UNLP), Consejo Nacional de Investigaciones Científicas y Técnicas (CONICET), Boulevard 120 S/N e/Avda. 60 y calle 64, 1900 La Plata, Buenos Aires, Argentina, ${ }^{5}$ UNLP, FCNYM, División Entomología, Museo de La Plata, Paseo del Bosque s/n, 1900 La Plata, Argentina, ${ }^{6}$ Universidad Nacional de Córdoba CONICET, IMBIV, Centro de Relevamiento y Evaluación de Recursos Agrícolas y Naturales (CREAN), Av. Valparaíso s/n. CC 509, 5000 Córdoba, Argentina, 'Universidad Nacional de Córdoba, Facultad de Ciencias Exactas, Físicas y Naturales, Cátedra de Ecología, Av. Vélez Sársfield 299, Córdoba, Argentina, and ${ }^{8}$ Corresponding author, E-mail: florentina.diaz@gmail.com

Received 26 December 2017; Editorial decision 31 January 2018

\begin{abstract}
The fourth instar larva and pupa of Culicoides trilineatus Fox (Diptera, Ceratopogonidae), a species considered as potential vector of the bluetongue virus in Central and South America, are described, illustrated, and photomicrographed for the first time by using binocular, phase-contrast, and scanning electron microscopy. The immatures were collected by using a siphon bottle in tree holes in Salta Province, Argentina, transported to the laboratory, and there reared to the adult's emergence. They are compared with the immatures of Culicoides debilipalpis Lutz (Diptera, Ceratopogonidae), another Neotropical species that develops in tree holes. Details on larval biology and habitat are given.
\end{abstract}

Key words: Culicoides, Ceratopogonidae, larva, pupa, phytotelmata

The Diptera family Ceratopogonidae is placed in the infraorder Culicomorpha (Borkent 2012). It includes six subfamilies, of which 4 are extant and worldwide in distribution, with 111 extant genera and 6,267 species, and fossil records include 21 genera and 284 species (Borkent 2016). The larval habitats of Ceratopogonidae are generally poorly known but include semiaquatic habitats ranging from mud at the soil-water interface, to moist and highly organic soil substrates and intact dung pats (Purse et al. 2015). In addition, they also occur in phytotelmata, aquatic microenvironments formed by the accumulation of water in any part of plants such as leaves, flowers, stems, trunks, and tree holes (Campos et al. 2011).

The adult females of the genus Culicoides Latreille (Diptera, Ceratopogonidae) are hematophagous. They are known as 'biting midges', 'no-see-ums' or 'punkies' in English speaking countries, 'polvorines', 'manta blanca', 'chaquistes' or 'jejenes' (common name shared with Simuliidae) in Spanish speaking countries, and 'mosquito pólvora' or 'maruim' in Brazil (Spinelli and Ronderos 2005). Many species are involved in the transmission of arboviruses, protozoa, and filarial nematodes that cause diseases in both humans and animals (Borkent and Spinelli 2007). One of the most important of these diseases is caused by bluetongue virus (BTV), which attacks sheep, cattle, goats, and wild ruminants, causing hemorrhage and ulceration in the upper gastrointestinal tract as well as laminitis, coronitis, facial and neck edema, pulmonary edema, reproductive failures, and lameness (Mellor et al. 2009). Information about BTV in Central America, the Caribbean, and South America is limited. The traditional idea claims that BTV spread is limited to latitudes $35^{\circ} \mathrm{S}$ and $40^{\circ} \mathrm{N}$ or $50^{\circ} \mathrm{N}$ (Coetzee et al. 2012), almost all the American continent. Latitude $35^{\circ} \mathrm{S}$ reaches Central Argentina and nearly all the Pampas region, where the main cattle production is carried out, whereas latitude $50^{\circ} \mathrm{N}$ reaches southern Canada. Nowadays, it is empirically known that BTV is widely spread between those limits, an idea supported mainly by serologic evidence (Legisa et al. 2013). Regarding the vector species suspected to be responsible for BTV transmission among ruminants, Walton and Osburn (1992), Greiner et al. (1990), and Mo et al. (1994) isolated BTV from Culicoides insignis Lutz (Diptera, Ceratopogonidae), Culicoides filarifer Hoffman (Diptera, Ceratopogonidae), and Culicoides pusillus Lutz (Diptera, Ceratopogonidae) in Central America. Additionally, they suggested that these three species, mainly C. insignis, were the primary species involved in the virus transmission in the region, pointing out that other species which could act as vectors in that region are C. pusillus, Culicoides furens Poey (Diptera, Ceratopogonidae) and C. trilineatus Fox. Since 1996 Argentina has been considered serologically positive according to OIE parameters 
(Gorchs and Lager 2001), and the virus (serotype 4) has been isolated from cattle in Corrientes province (Gorchs et al. 2002, Lager 2004, Legisa et al. 2014, Veggiani Aybar et al. 2016). Although the southern boundary of BTV reaches the central region of the country, recent climate change around the world makes necessary a new configuration of those boundaries.

During a sampling program focused on the collection and study of Diptera carried out in Salta province between 2012 and 2013, larvae and pupae of C. trilineatus were collected from tree holes and reared to adults. The aim of this work is to provide for the first time the description of these immatures that belong to a species suspected to be a vector of BTV.

\section{Materials and Methods}

\section{Study Area}

San Ramon de la Nueva Orán, hereafter Orán, is located in northwestern Argentina, $270 \mathrm{~km}$ from the city of Salta and $44 \mathrm{~km}$ from the border with Bolivia $\left(23^{\circ} 08^{\prime} \mathrm{S}, 64^{\circ} 20^{\prime} \mathrm{W}\right.$, elevation $\left.337 \mathrm{~m}\right)$. The climate is subtropical, with an average summer temperature of $27.7^{\circ} \mathrm{C}$ and winter temperature of $16.4^{\circ} \mathrm{C}$. The mean annual rainfall is $1,000 \mathrm{~mm}$, occurring mostly during the warmer months (October to April). Orán is included in the pedemontane floor of the Yungas subtropical montane moist forest, where jungles of Palo Blanco (Calycophyllum multiflorumy Griseb; Rubiales: Rubiaceae) and Palo Amarillo (Phyllostylon rhamnoides (Poisoon) Taub; Urticales: Ulmaceae) predominate. Vines are also important in pedemontane areas (Brown et al. 2001). The area has been subjected to ecological modifications related to human activities, mainly urbanization, industrialization, agriculture, and forestry (Brown et al. 2001). The city is characterized by a densely built central area where houses with small or no front yards predominate and there are few low buildings. Suburban areas have a lower building density with bigger gardens, more trees, and are closer to the border with the seminatural region.

\section{Entomological Sampling}

Specimens were collected during field sampling carried out from January to April in 2012 and 2013, as a part of a larger study on mosquitoes (Diptera: Culicidae) larval habitats. Samples were collected from tree holes using a siphon bottle, following the procedure described by Müller and Marcondes (2007) and Mangudo et al. (2010). For details on tree holes selection, see Mangudo et al. (2017).

The specimens were carried to the laboratory, four of the collected larvae reached the pupal stage very early, before placing them in separate vials. Larval exuviae and larvae were preserved in ethanol $70 \%$ and pupae were kept alive isolated in plastic vials $(2 \mathrm{~mm})$ holding water from the tree hole and containing a piece of humid filter paper, to maintain the humidity inside the vials. All emerging adults were C. trilineatus, and larvae characteristics matched those of the exuviae, thus they were all assumed to belong to the same species. They were observed daily until adult emergence. After that emergence adults were maintained alive for $24 \mathrm{~h}$ to ensure their final pigmentation. Adults and their respective exuviae were stored in vials containing ethanol $70 \%$. Larval exuviae, pupal exuviae, and adults were mounted in Canada balsam following the technique described by Borkent and Spinelli (2007). For scanning electron microscopy (SEM), larvae and pupae were prepared following the technique of Ronderos et al. (2000, 2008). Illustrations were made with pen and ink using an attached camera lucida. Photomicrographs were taken with a Micrometrics SE Premium digital camera, through a Nikon Eclipse E200 microscope.
For larval terms, see Ronderos et al. (2010) and Borkent (2014) for pupae.

The plates were made in TIFF format in Adobe Photoshop version 14. The studied material is deposited in the División Entomología, Museo de La Plata (MLPA), La Plata, Argentina.

\section{Results}

\section{Culicoides trilineatus Fox}

(Figs. 1-4)

Culicoides trilineatus Fox 1946: 250 (female; Virgin Islands); Fox 1949: 30 (male; Puerto Rico); Forattini 1957: 389 (redescription; distribution); Wirth and Blanton, 1956: 189 (redescription; distribution); Cavalieri and Chiossone 1966: 149 (distribution in Argentina); Vitale et al. 1981: 146 (in key to species in the debilipalpis group); Wirth et al. 1988: 50 (in Neotropical Wing Atlas; distribution); Borkent and Spinelli 2000: 42 (in New World catalog south of the United States; distribution); Spinelli et al. 2005: 13 (in review of hematophagous Ceratopogonidae of Argentina; Paraguay record; in key; wing photograph); Borkent and Spinelli 2007: 75 (in Neotropical catalog; distribution).

Culicoides (Oecacta) trilineatus: Wirth 1974: 36 (in New World catalog south of the United States; distribution).

\section{Fourth Instar Larva (Figs. 1A-D, 2A-D, and 3A-C)}

Coloration whitish in life. Head capsule yellowish, moderately elongate, apex slightly bent ventrally, all setae simple, moderately thin, medium-sized to elongate (Figs. 1A-C and 3A); chaetotaxy as in Fig. $1 \mathrm{~B}$ and C. HL (head length) $0.205-0.210(0.206, n=4)$ $\mathrm{mm}$; HW (head width) $0.12-0.15(0.13, n=4) \mathrm{mm}$; HR (head ratio) 1.36-1.75 (1.56, $n=4)$; SGW (subgenal width) 0.10-0.12 (0.11, $n=4) \mathrm{mm}$; SGR (subgenal ratio) $1.12-1.25(0.19, n=4)$. Antennae short, cylindrical (Figs. 1C, D and 2A). Labrum (Figs. 1C, D and 3A, B) 0.64 times longer than wide, with three pairs of anterolateral sensilla styloconica (Fig. 2A-C); palatum (Figs. 1D and 2A-C) with four pairs of sensilla trichoidea closely spaced, anterior sensillum long, posterior of them three medium-sized (Fig. 2A-C); messors well developed, stout, with four to five angulate teeth (Fig. 2A-C); scopae well developed, with apparently 8-10 elongate, strong, pointed teeth (Fig. 2A-C). Maxilla (Figs. 1B, D and 2A) well sclerotized; galeolacinia (Fig. 2B and C) with three-four papillae and with long seta; maxillary palpus (Fig. 2C) medium-sized, cylindrical, with two-three apical papillae; lacinial sclerite 1 without seta, lacinial sclerite 2 with long, thin seta (Fig. 2A-C).

Mandible (Figs. 1C, D and 3A, B) hooked, curved, with broad base, with distinct subapical notch and associated rounded prominence, one sensory pit and one medium-sized seta on the aboral surface, prominent point of articulation, two teeth, apical elongate, pointed tooth, the inner tooth smaller; MDL (mandible length) 0.040-0.055 (0.046, $n=3$ ) mm; MDW (mandible width) 0.012$0.015(0.014, n=3) \mathrm{mm}$. Hypostoma (Figs. 1C, D and 2A-C) with quadrangular mesal serrate elevation, lateral margin with five to six strong teeth, the first smaller than the lasted tooth. Labium elongate, not extending beyond hypostoma. Epipharynx (Fig. 3A-C) massive, strongly sclerotized, two comb present, with dorsal comb moderately wide and rounded posteriorly, with eight to nine elongate, subequal teeth, the central tooth stouter than other, ventral comb with 10-12 small, lancelate, thin teeth; lateral arms stout, elongate, with lateral curtains with finely pointed teeth of moderate length (Fig. 3B and C); LAW (the width across the lateral arms of epipharynx) $0.07-$ $0.09(0.08, n=4) \mathrm{mm}, \mathrm{DCW}$ (width across each of the paired dorsal 

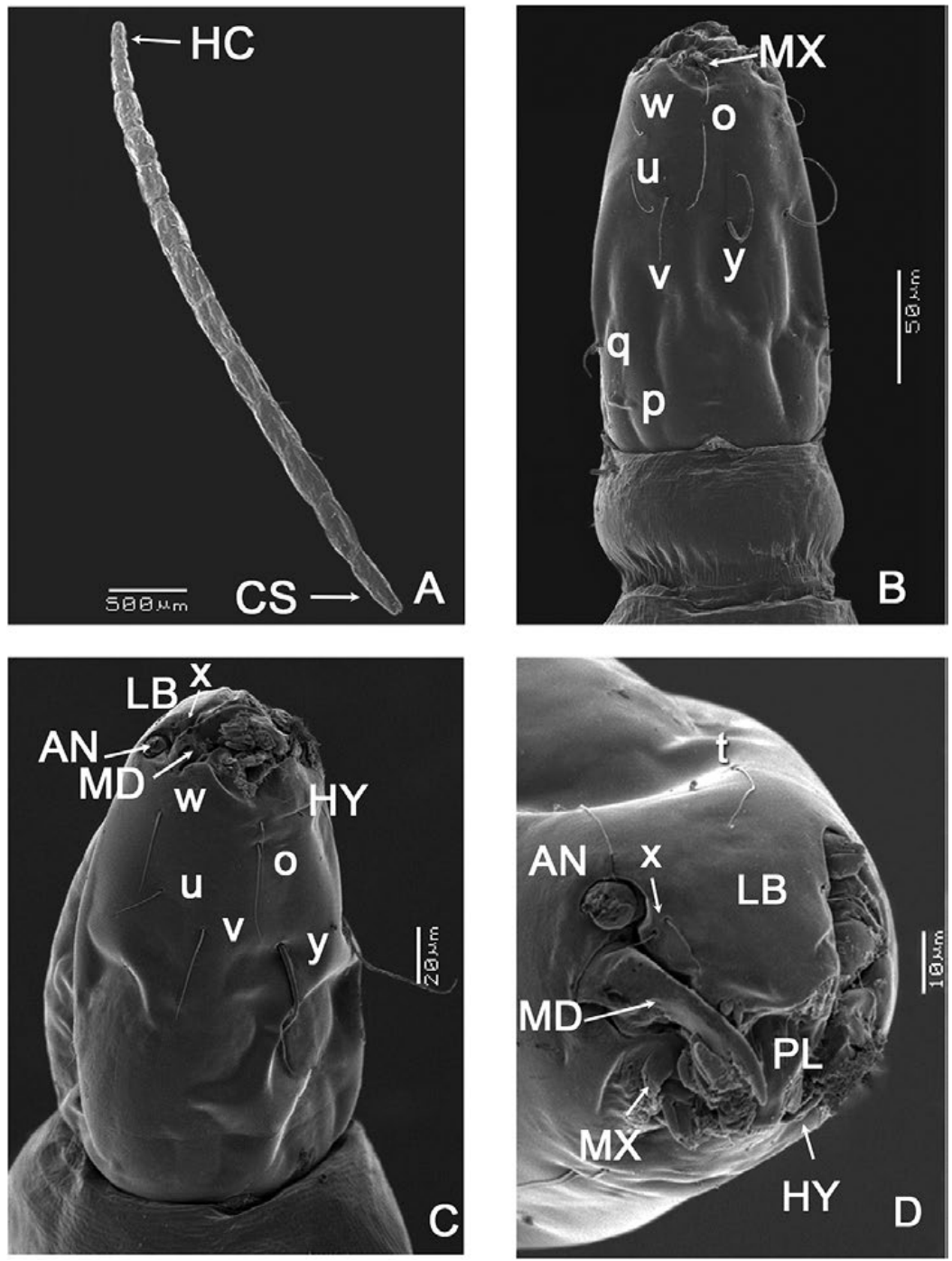

Fig. 1. Scanning electron micrographs of larva Culicoides trilineatus Fox (Diptera: Ceratopogonidae) collected in Argentina: entire larva (A); head capsule, lateroventral view (B); head capsule, ventral view (C); head capsule, laterofrontal view (D). AN, antennae; CS, caudal segment; GL, galeolacinia; HC, head capsule; HY, hypostoma; LB, labrum; MD, mandible; MX, maxilla; PL, palatum; ss, sensilla styloconica; st, sensilla trichoidea. Head capsule chaetotaxy are indicated by single letters: 0 , parahypostomal setae; $t$, prefrontal setae; $u$, mesolateral setae; $v$, posterolateral seta; $w$, anterolateral setae; $x$, parantennal setae; $y$, ventral setae.

comb sclerites of the epipharynx) $0.027-0.030(0.028, n=4) \mathrm{mm}$. Hypopharynx (Fig. 3A-C) elongate, thin, moderately sclerotized, without fringe. Thoracic pigmentation diffuse. Abdominal segment whitish. Caudal segment (Fig. 2D) with four anal papillae and six pairs of setae: 'o', 'i' long, thin setae; $l_{1}$ and $1_{2}$ medium-sized, thin setae, $v, d$, short, thin setae; CSL (caudal segment length) 0.46-0.50 $(0.48, n=3)$; CSW (caudal segment width) $0.56-0.60(0.58, n=3)$; CSR (caudal segment ratio) 2.09-3.5 $(2.48, n=3$ ); OL (length of the caudal seta "o") $0.067-0.075(0.070, n=3)$; OD (length of the caudal seta "o") 0.015-0.022 $(0.019, n=3)$.

Female Pupa (Figs. 3D, E, I and 4A, C-E)

Habitus as in Fig. 3D. Exuviae general coloration pale brown. Total length 2.32-2.60 (2.42, $n=3) \mathrm{mm}$. Head: Dorsal apotome (Fig. 3E) $1.45 \times$ broader than long, apex apparently truncated, surface covered with small rounded spinules, distal margin truncate, smooth with two pairs of raised, wrinkles areas; dorsal apotome sensilla (Fig. 3E): DA-1-H elongate, thin seta, insert in well-developed tubercle, DA-2-H basal campaniform sensillum; disc surface covered by stout, rounded spinules; DAL (dorsal apotome length) 0.13-0.16 (0.14, $n=3) \mathrm{mm}$; DAW (dorsal apotome width) 0.20-0.21 (0.205, $n=3$ ) $\mathrm{mm}$; DAW/DAL (maximum width, between lateral angles) 1.28-1.61 $(1.45, n=3)$. Mouthparts as in Fig. 4A. Sensilla: two dorsolateral cephalic sclerite sensilla: DL-1-H long, thin seta, DL-2-H stout, short setae; without clypeal/labrals; three ocular (Fig. 4A): O-1-H, O-3-H long, thin setae; O-2-H campaniform sensillum. Thorax: Prothoracic extension absent; respiratory organ (Fig. 3D) pale brown, nearly straight, with scale-like spines, with seven to eight apical and two lateral pores; RO length (respiratory organ length) $0.155-0.160$ $(0.158, n=3) \mathrm{mm}, \mathrm{RO}$ width (respiratory organ width) $0.03(n=3)$ $\mathrm{mm}$; pedicel short, stout; length $0.025-0.03(0.028, n=3)$; ROP/ RO (respiratory organ pedicel length / respiratory organ length): 0.15-0.19. Sensilla: one anteromedial sensillum: AM-1-T mediumsized, thin seta, three anterolateral sensilla: AL-1-T, AL-2-T long, thin setae, AL-3-T short, stout seta; dorsals (Fig. 4C): D-1-T, D-2-T, D-4$\mathrm{T}$; D-5-T medium-sized, thin setae, D-3-T campaniform sensillum, supraalar (SA-2-T) campaniform sensillum. Metathoracics (Fig. 4D): M-2-T long thin seta, M-3-T campaniform sensillum. Cephalothorax 

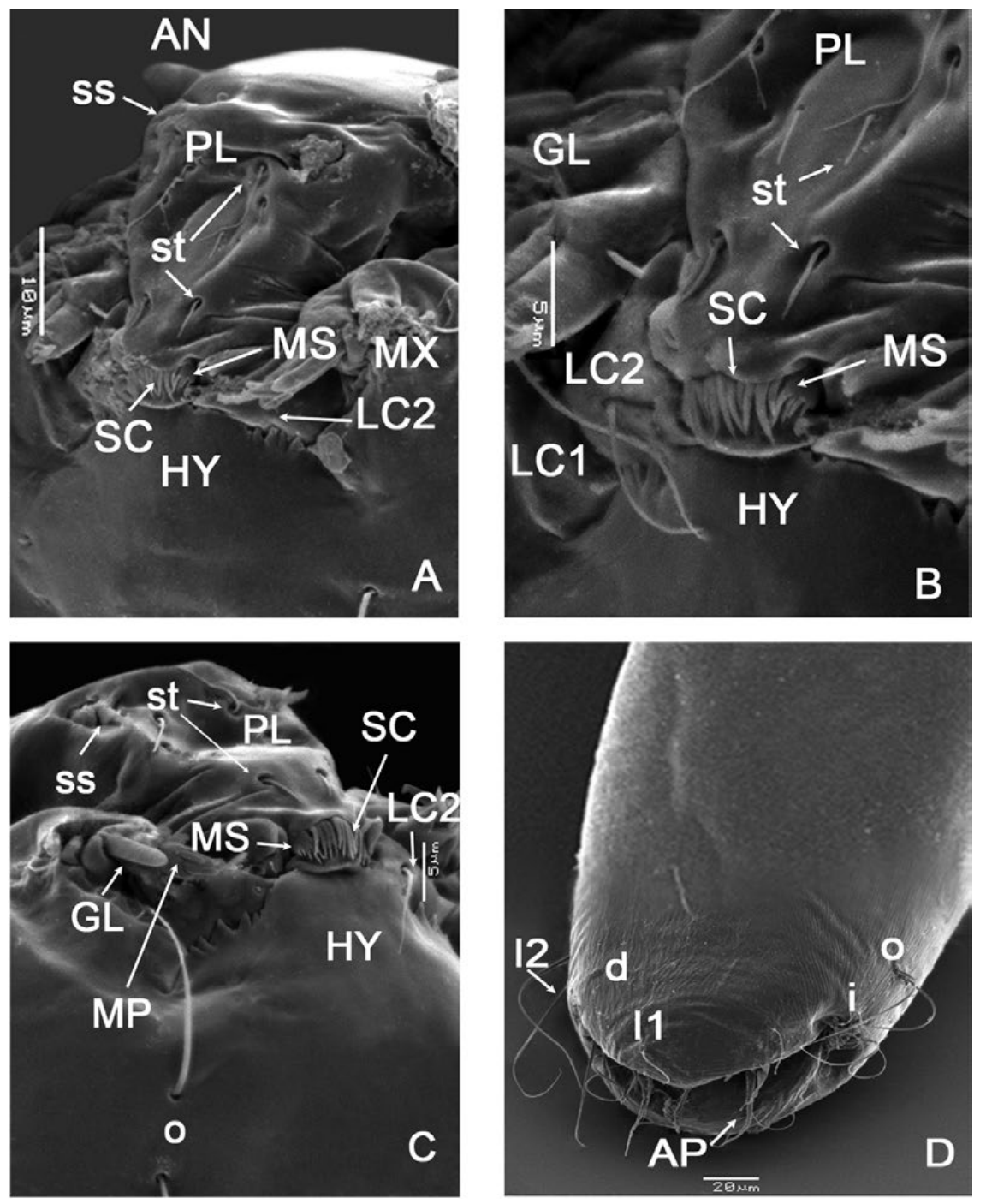

Fig. 2. Scanning electron micrographs of larva Culicoides trilineatus Fox (Diptera: Ceratopogonidae) collected in Argentina: palatum, messors, and scoope (A); detail palatum (B); detail maxilla (C); caudal segment, dorsal view (D). AN, antennae; AP, anal papillae; GL, galeolacinia; HY, hypostoma; LC2, lacinial sclerite 2; LCT, lateral curtains; MD, mandible; MX, maxilla; MP, maxillary palpus; MS, messors; PL, palatum; SC, scopae; ss, sensilla styloconica; st, sensilla trichoidea. Caudal segment chaetotaxy: 'd', dorsal setae; ' $i$ ', inner seta; 'll', first lateral seta; ' ${ }_{2}{ }^{\prime}$, second lateral seta; 'o', outer seta; ' $p$ ', posterior perifrontal seta; ' $q$ ', postfrontal setae; 'v', ventral setae.

surface with small rounded tubercles, length $0.85-0.95(0.90, n=3)$ mm, width $0.60-0.67(0.64, n=3) \mathrm{mm}$. Abdomen: abdominal segments covered with small spinules on anterior margin, posterior margin smooth. Sensilla: tergite 1 (Fig. 4D) with setae as follows: D-2-I, D-3-I long, thin setae; D-4-I, D-7-I campaniform sensilla; D-8-I medium-sized, thin seta; D-9-I long, thin seta; L-1-I long, thin seta, L-2-I, L-3-I short, thin setae. Second abdominal segment similar to the first one; segment 4 with sensillar pattern (Fig. 4E) as follows: D-2-IV, D-3-IV long, thin setae; D-2-IV longer than D-3-IV; D-4-IV, D-7-IV campaniform sensilla, D-5-IV minute seta, D-8-IV, D-9-IV long, thin setae, D-8-IV stouter than D-9-IV, all located on flattened tubercles; L-1-IV, L-2-IV, L-4-IV short, stout setae, L-3-IV long, thin seta, all located on triangular tubercles; V-5-IV short, stout seta, V-6-IV, V-7-IV long, thin setae, V-7-IV longer than V-6-IV. Segment 9 (Fig. 3D and I) $1.62 \mathrm{X}$ longer than wide, ventral surface with many spicules; length $0.23-0.25(0.24, n=3) \mathrm{mm}$, width $0.14(n=3) \mathrm{mm}$. Terminal process (Fig. 3D and I) triangular, elongated, subparallel, pointed, ventral surface of processes spiculate, with D-5-IX, D-6-IX campaniform sensilla, length $0.08-0.10(0.09, n=3) \mathrm{mm}$.
Male Pupa (Figs. 3F-H, J and 4B)

Similar to female with usual sexual differences. Total length 2.30$2.40(2.35, n=3) \mathrm{mm}$. Exuvium pale brown. Dorsal apotome (Fig. 3F) with DAL $0.17 \mathrm{~mm}$; DAW $0.17 \mathrm{~mm}$, DAW/DAL 1.00 . Cepahalothoracic sensilla as in Figs. 3G, $\mathrm{H}$ and 4B. Respiratory organ (Figs. 3G, H and 4B), RO length $0.15-0.16(0.155, n=3) \mathrm{mm}$, RO width $0.04(n=3)$; pedicel length $0.025-0.30(0.028, n=3)$. Cephalothorax: length $0.92-0.95(0.93, n=3) \mathrm{mm}$, width $0.60-0.65$ $(0.62, n=2) \mathrm{mm}$. Segment 9 (Fig. 3J) length $0.26(0.25-0.27, n=3)$ $\mathrm{mm}$, width $0.15-0.18(0.16, n=3) \mathrm{mm}$; genital lobe (Fig. $3 \mathrm{~J})$ reaching the posterior margin of segment; terminal process length $0.09-$ $0.11(0.10, n=3) \mathrm{mm}$.

\section{Material Examined}

ARGENTINA: Salta: three males (with pupal exuviae), three females (with pupal exuviae), San Ramón de la Nueva Orán; $23^{\circ} 8^{\prime} 55.09^{\prime \prime}$ S, 64 $19.24^{\prime} 82^{\prime \prime} \mathrm{W}, 13-\mathrm{III}-2013$, C. Mangudo; same data except $23^{\circ} 8^{\prime} 29.16^{\prime \prime}$ S, $64^{\circ} 18^{\prime} 31.03^{\prime \prime} \mathrm{W}, 26-\mathrm{II}-2012$, four larval exuviae. 


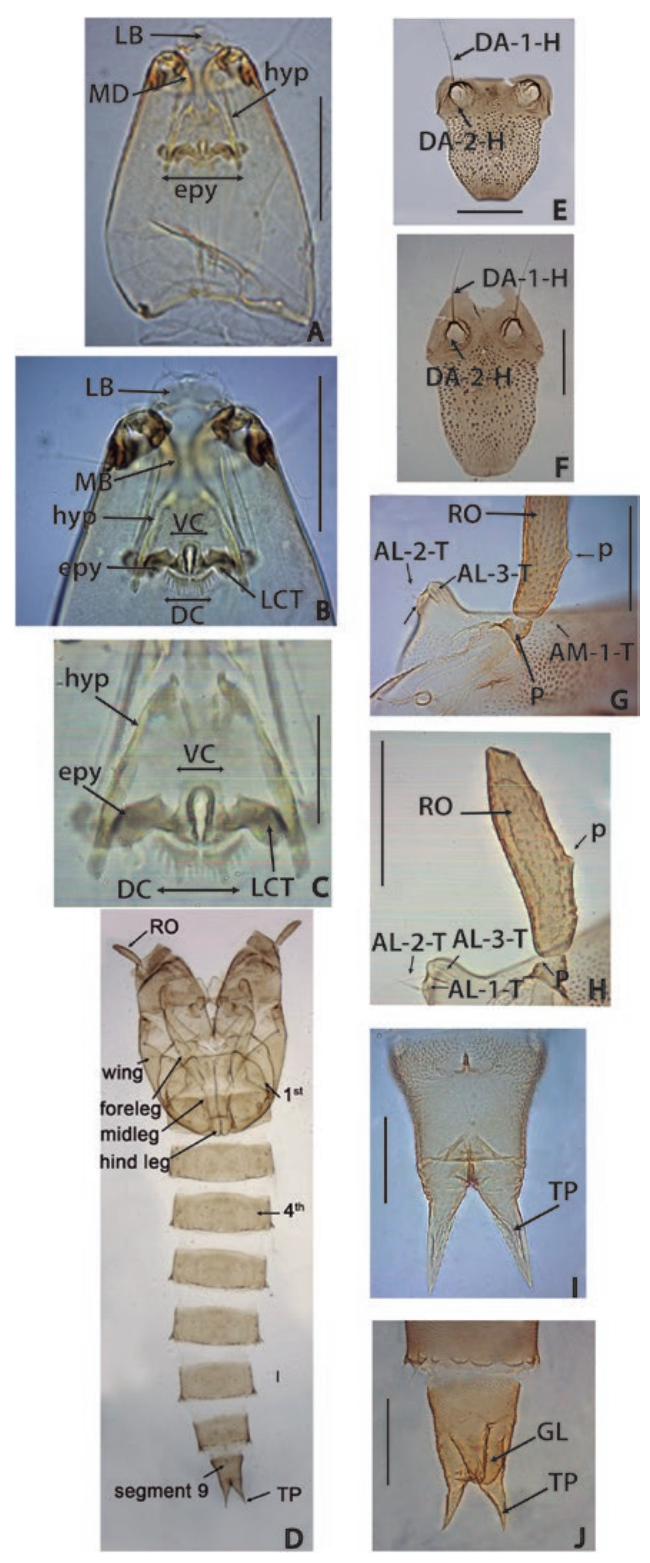

Fig. 3. Larva and pupa of Culicoides trilineatus Fox (Diptera: Ceratopogonidae) collected in Argentina: Larva (A-C); female pupa (D-E, I); male pupa (F-H, J): head capsule (A); head capsule, anteroventral view (B); detail epipharynx (C); entire pupa (D); dorsal apotome (E-F); anteromedial and anterolateral sensilla (G); respiratory organ (H); segment 9 (I-J). AL-1-T, AL-2-T, AL-3-T, anterolateral sensilla; AM-1-T, AM-2-T, AM-3-T, anteromedial sensilla; DA-1-H, D-2-H, dorsal apotome sensilla; DC, dorsal comb; epi, epipharynx; GL, genital lobe; hyp, hypopharynx; LTC lateral curtains; MD, mandible; LB, labrum; P pedicel; $p$, pore; $\mathrm{RO}$, respiratory organ; $\mathrm{TP}$, terminal process; $\mathrm{VC}$, ventral comb.

\section{Material Examined by SEM}

ARGENTINA: Salta: two larvae, one pupa, San Ramón de

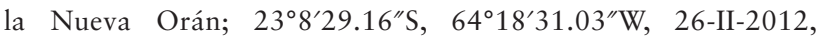
C. Mangudo, MLPA.

Type Material: Holotype female (mounted in balsam on a slide), Virgins Islands, St. Thomas, 11-IX-1937, biting in afternoon. In the collection of the School of Tropical Medice, University of Puerto Rico, San Juan, Puerto Rico.

\section{Distribution}

Guatemala to Panama, Puerto Rico, Virgin Islands, Dominica, Barbados, Paraguay, Argentina (Salta, Formosa, Chaco, Misiones).

\section{Discussion}

C. trilineatus was originally described by Fox (1946) from St. Thomas, Virgin Islands, based on a couple of females biting humans in the afternoon. Posteriorly Fox (1949) described the male from a specimen reared after out of tree hole debris at Luquillo, Puerto Rico. Subsequently, the adult female was redescribed by Wirth and Blanton (1956). This species was assigned by Wirth (1974) to the subgenus Oecacta and by Vitale et al. (1981) to the debilipalpis group. However, Borkent and Spinelli $(2000,2007)$ in the Neotropical catalog did not assign it to any specific group or subgenus, including it in the Miscellaneous Unplaced species section. The reared female and male adults were identified as C. trilineatus, by the comparison with the above mentioned descriptions.

The larva and pupa of C. trilineatus are very similar to C. debilipalpis, a species that also breeds in tree holes, and whose immatures were fully described by Ronderos et al. (2010).

The larva of C. trilineatus resembles C. debilipalpis by virtue, the cylindrical maxillary palpus, galeolacinia with a long seta, hooked mandible, hypostoma with quadrangular mesal elevation and lateral margin with teeth; elongate and thin, hypopharynx without fringe and caudal segment with six pairs of setae. However, C. debilipalpis differs by the smaller head capsule $(0.14-0.17 \mathrm{~mm})$, the labrum has a pair of the sensilla styloconica, the labrum is as long as its greatest width and with three pairs of the sensilla trichoidea, the labium is distinctly smaller, the epipapharynx has two ventral combs and one dorsal comb, the latter with 22-24 small teeth, and caudal segment without anal papillae. The pupa of C. debilipalpis is readily distinguished from C. trilineatus by the yellowish exuviae, the yellowish respiratory organ except its distal half dark brown, and by the presence of two clypeal/labrals and the minute D-8-I. Ronderos et al. (2010) incorrectly mentioned the presence of one dorsal cephalic sclerite sensillum, two oculars, and two anterolaterals for C. debilipalpis, but a detailed revision of the pupa of this species during the present study revealed the presence of the two dorsal cephalic sclerite sensilla, three oculars, and three anterolateral sensilla.

\section{Perspective}

Because the change in global climate driven by global warming could contribute to the creation of more adequate conditions for the propagation and reproduction of the Culicoides spp. suspected to act as vectors of pathogens, the proper knowledge of the larval habitats and the accurate identification of their immatures would be extremely important in order to develop programs for the early detection of hatcheries and in this way avoid outbreaks that can spread the disease.

\section{Biology}

Larvae and pupae of C. trilineatus were collected in tree holes between January to April in 2012 and 2013. The tree holes were pans formed as branch intersections (maintaining an unbroken bark lining) in a Delonix regia (Bojer) Raf. (Fabales: Fabaceae) and a Broussonetia papyrifera (L.) Vent. (Rosales: Moraceae). The specimens described herein were collected from urban tree holes, but the species was also detected in holes from trees in yunga forest patches to the east of the city.

The C. trilineatus immatures were found either as single species when the volume of water was very low $(>25 \mathrm{cc}$ ) or coexisting with Aedes aegypti L. (Diptera, Culicidae), Aedes terrens (Walker) (Diptera, Culicidae), and/or Haemagogus spegazzini Brèthes (Diptera, Culicidae) (water volume ranging from 300-600 cc). A. aegypti is the main global vector of dengue, urban yellow fever, zika, and chikungunya virus 

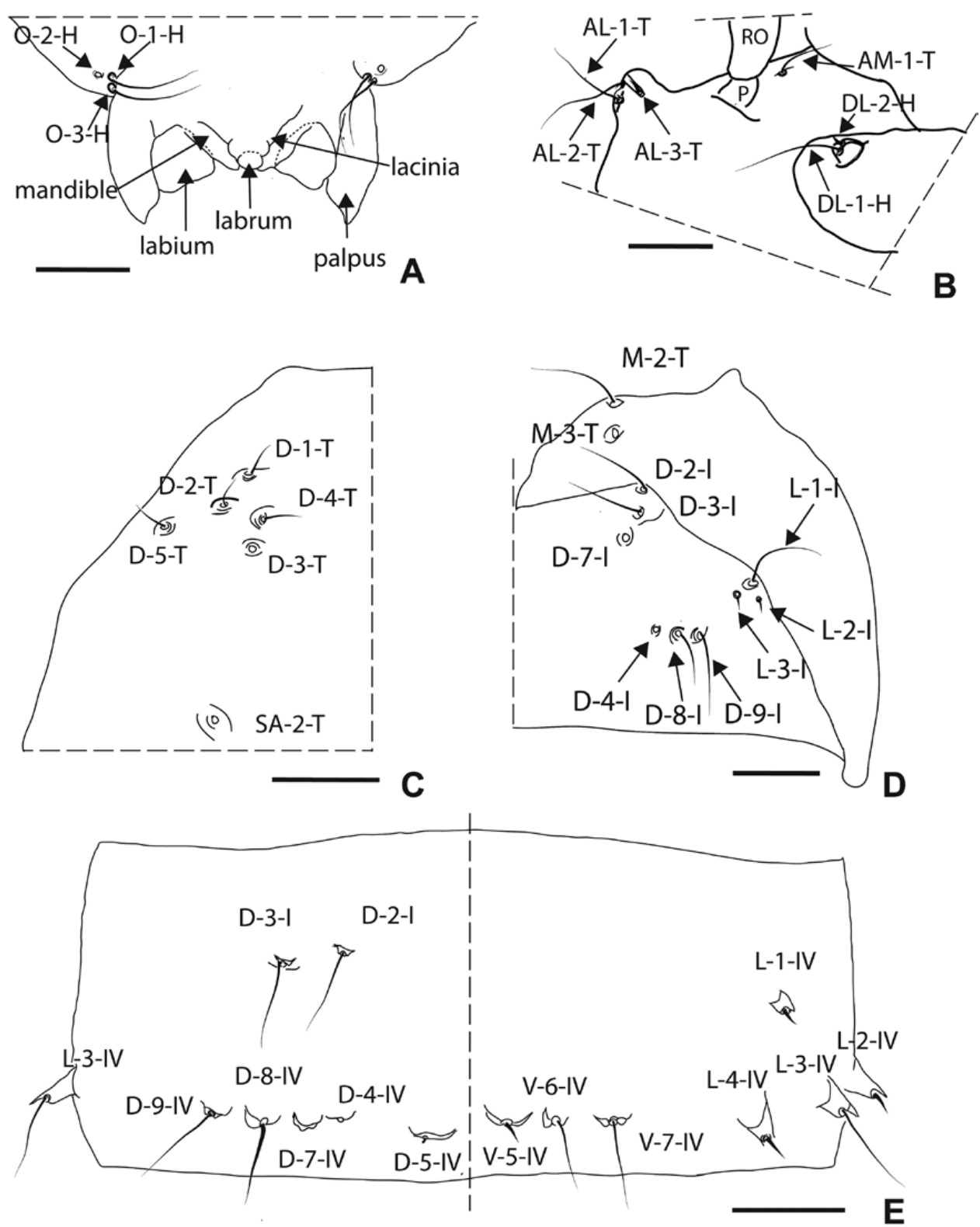

Fig. 4. Draw of pupa Culicoides trilineatus Fox (Diptera: Ceratopogonidae) collected in Argentina: Female pupa (A, C-E); male pupa (B): Mouthparts and ocular sensilla (A); Cephalothoracis sensilla (B); dorsal sensilla (C); metathorax and tergite 1 (D); segment 4 (E). Scale bars: 0.05 mm. AL-1-T, AL-2-T, AL-3-T, anterolateral sensilla; AM-1-T, anteromedial sensilla; D-1-T, D-2-T, D-3-T, D-4-T, D-5-T, dorsal sensilla; DL-1-H, DL-2-H, dorsolateral cephalic sclerite sensilla; M-2-T, M-3-T, metathoracic sensilla; O-1-H, O-2-H, O-3-H, ocular sensilla; P, pedicel; RO, respiratory organ; D-1-IV, D-2-IV, D-3-IV, D-4-IV, D-5-IV, D-7-IV, D-8-IV, D-9-IV, L-1-IV, L-2-IV, L-3-IV, L-4-IV, V-1-IV, V-5-IV, V-6-IV, V-7-IV, segment 4 sensilla, D-1-I, D-2-I, D-4-I, D-7-I, D-8-I, D-9-I, L-1-I, L-2-I, L-3-I, tergite 1 sensilla.

(Gubler 2004, Ayres 2016, Marcondes et al. 2017), and Haemagogus (Diptera, Culicidae) species are involved in sylvan yellow fever and potentially other arbovirus transmission in South America (Karabatsos 1985). These findings highlight the importance of phytotelmata as larval habitat for dipterous of medical relevance in urban settings.

\section{Acknowledgements}

We are very grateful to Prof. Laura Morote for her help with the design of illustrations. C.M. holds a post-doctoral scholarship from CONICET. F.D., R.M.G., G.R.S., and M.M.R. are career members of CONICET-Argentina. We acknowledge funding from SECYT-Universidad Nacional de Córdoba (grant number 11420090100245) and PIP CONICET (grant number $11220130100315 \mathrm{CO}$ and $11220120100305 \mathrm{CO} 01)$.

\section{References Cited}

Ayres, C. F. J. 2016. Identification of Zika virus vectors and implications for control. Lancet Infect. Dis. 16: 278-279.

Borkent, A. 2012. The pupae of Culicomorpha-morphology and a new phylogenetic tree. Zootaxa 3396: 1-98.

Borkent, A. 2014. The pupae of the biting midges of the world (Diptera: Ceratopogonidae) with an analysis of the phylogenetic relationships between genera. Zootaxa 3879: 1-327.

Borkent, A. 2016. World species of biting midges (Diptera: Ceratopogonidae). http://www.inhs.uiuc.edu/research/FLYTREE/CeratopogonidaeCatalog.pdf.

Borkent, A., and G. R. Spinelli. 2000. Catalog of the New World biting midges south of the United States of America (Diptera: Ceratopogonidae), pp. 01-107. Contributions on Entomology, International. Associated Publishers, Gainesville, FL. 
Borkent, A., and G. R. Spinelli. 2007. Neotropical Ceratopogonidae (Diptera: Insecta), pp. 1-98. In J. Adis, J. R. Arias, G. Rueda-Delgado, and K. M. Wantzen (eds.), Aquatic biodiversity in Latin America (ABLA), vol. 4. Pensoft, Sofia-Moscow.

Brown, A. D., H. R. Grau, L. Malizia, and A. Grau. 2001. Los bosques nublados de la Argentina, pp. 623-659. In A. D. Brown and M. Kappelle (eds.), Bosque nublados de Latinoamerica. Editorial INBio, Costa Rica.

Campos, R. E., G. R. Spinelli, and M. Motoyoshi. 2011. Culicidae and Ceratopogonidae (Diptera: Nematocera) inhabiting phytotelmata in Iguazu National Park, Misiones province, subtropical Argentina. Rev. Soc. Entomol. Argent. 70: 11-118.

Cavalieri, F., and I. Chiossone. 1966. Sobre el conocimiento actual del género hematófago Culicoides Latreille, 1809, en la Argentina (Diptera, Ceratopogonidae). Physis 26: 145-153.

Coetzee, P., M. Stokstad, E. H. Venter, M. Myrmel, and M. Van Vuuren. 2012. Bluetongue: a historical and epidemiological perspective with the emphasis in South Africa. Virol. J. 9: 198.

Forattini, O. P. 1957. Culicoides da Região Neotropical (Diptera: Ceratopogonidae) Arquivos da Faculdade de Higiene e Saúde Publica Univ. São Paulo 11: 159-526.

Fox, I. 1946. A review of the biting midges or Culicoides from the Caribbean region (Diptera: Ceratopogonidae). Ann. Entomol. Soc. Am. 39: 248-258.

Fox, I. 1949. Notes on Puerto Rican biting midges or Culicoides (Diptera: Ceratopogonidae). Bull. Brook. Entomol. Soc. 44: 29-34.

Gorchs, C., and I. Lager. 2001. Lengua Azul. Actualización sobre el Agente y la Enfermedad. Rev. Argent. Microbiol. 33: 122-132.

Gorchs, C., A. Vagnozzi, S. Duffy, J. Miquet, J. Pacheco, A. Bolondi, G. Draghi, B. Cetra, C. Soni, M. M. Ronderos, et al. 2002. Lengua Azul: aislamiento y caracterización del virus e identificación de vectores en el noreste argentino. Rev. Argent. Microbiol. 34: 150-156.

Greiner, E. C., W. I. Knausenberger, M. Mesersmith, W. L. Kramer, and E. P. J. Gibbs. 1990. Culicoides spp. (Diptera: Ceratopogonidae) associated with cattle in St. Croix, Virgin Islands, and their relevance to bluetongue viruses. J. Med. Entomol. 27: 1071-1073.

Gubler, D. J. 2004. The changing epidemiology of yellow fever and dengue, 1900 to 2003: full circle? Comp Immunol. J. Microbiol. Infect. Dis. 27: 319-330.

Karabatsos, N. 1985. International catalogue of arboviruses including certain other viruses of vertebrates. Published for the Subcommittee on Information Exchange of the American Committee on Arthropod-borne Viruses by the American Society of Tropical Medicine and Hygiene, San Antonio, TX.

Lager, I. A. 2004. Bluetongue virus in South America: overview of viruses, vectors, surveillance and unique features. Vet. Ital. 40: 89-93.

Legisa, D., F. Gonzalez, G. De Stefano, A. Pereda, and M. J. Dus Santos. 2013. Phylogenetic analysis of bluetongue virus serotype 4 field isolates from Argentina. J. Gen. Virol. 94: 652-662.

Legisa, D. M., F. N. Gonzalez, and M. J. Dus Santos. 2014. Bluetongue virus in South America, Central America and the Caribbean. Virus Res. 182: 87-94.

Mangudo, C., J. P. Aparicio, and R. M. Gleiser. 2010. Tree holes as larval habitats for Aedes aegypti in public areas in Aguaray, Salta province, Argentina. J. Vector Ecol. 36: 227-230.

Mangudo, C., J. P. Aparicio, and R. M. Gleiser. 2017. Tree hole mosquito species composition and relative abundances differ between urban and adjacent forest habitats in northwestern Argentina. Bull. Entomol. Res. 3: 1-10. doi: 10.1017/S0007485317000700.
Marcondes, C. B., M. Contigiani, and R. M. Gleiser. 2017. Emergent and reemergent arboviruses in South America and the Caribbean: why so many and why now? J. Med. Entomol. 54: 509-532.

Mellor, P., S. Carpenter, and D. White. 2009. Bluetongue in the insect host, pp. 295-321. In P. Mellor, M. Baylis, and P. Mertens, (eds.), Bluetongue monograph. Elsevier/Academic Press, London, United Kingdom.

Mo, C. L., L. H. Thompson, E. J. Homan, M. T. Oviedo, E. C. Greiner, J. González, and M. R. Sáenz. 1994. Bluetongue virus isolations from vectors and ruminants in Central America and the Caribbean. Am. J. Vet. Res. 55: 211-215.

Müller, G. A., and C. B. Marcondes. 2007. Immature mosquitoes (Diptera: Culicidae) on the bromeliad Nidularium innocentii in ombrophilous dense forest of Santa Catarina Island, Florianópolis, Santa Catarina State, southern Brazil. Biotemas 20: 27-31.

Purse, B. V., S. Carpenter, G. J. Venter, G. Bellis, and B. A. Mullens. 2015. Binomics of temperate and tropical Culicoides midges: knowledge gaps and consequences for transmission of Culicoides-borne viruses. Annu. Rev. Entomol. 60: 1-20.

Ronderos, M. M., C. G. Cazorla, and G. R. Spinelli. 2010. The immature stages of the biting midge Culicoides debilipalpis Lutz (Diptera: Ceratopogonidae). Zootaxa 2716: 42-52.

Ronderos, M. M., F. Díaz, and P. Sarmiento. 2008. A new method using acid to clean and a technique for preparation of eggs of biting midges (Diptera: Ceratopogonidae) for scanning electron microscope. Trans. Am. Entomol. Soc. 134: 471-476.

Ronderos, M. M., G. R. Spinelli, and P. Sarmiento. 2000. Preparation and mounting of biting midges of the genus Culicoides Latreille (Diptera: Ceratopogonidae) to be observed with a scanning electron microscope. Trans. Am. Entomol. Soc. 126: 125-132.

Spinelli, G. R., and M. M. Ronderos. 2005. Ceratopogonidae (Formas hematófagas), pp. 61-66. In O. D. Salomón (ed.), Artrópodos de interés medio en Argentina, Serie enfermedades transmisibles. Publicación monográfica 6, Buenos Aires, Argentina.

Spinelli, G. R., M. M. Ronderos, F. Díaz, and P. I. Marino. 2005. The bloodsucking biting midges of Argentina (Diptera: Ceratopogonidae). Mem. Inst. Oswaldo Cruz 100: 137-150.

Veggiani Aybar, C. A., R. A. Díaz Gomez, M. J. Dantur Juri, M. S. Lizarralde de Grosso, and G. R. Spinelli. 2016. Potential distribution map of Culicoides insignis Lutz (Diptera: Ceratopogonidae), vector of bluetongue virus, in Northwestern Argentina. J. Insect. Sci. 16: 1-7.

Vitale, G. C., W. W. Wirth, and T. H. G. Aitken. 1981. New species and records of Culicoides reared from arboreal habitats in Panama, with a synopsis of the debilipalpis group (Diptera: Ceratopogonidae). Proc. Entomol. Soc. Wash. 83: 140-159.

Walton, T., and B. Osburn. 1992. Bluetongue, African horse sickness and related orbiviruses, pp. 1088. In Proceedings of the Second International Symposium, 14 July 1992. CRC Press, Boca Raton, FL.

Wirth, W. W. 1974. Family Ceratopogonidae. In A catalog of the Diptera of the Americas south of the United States. Fasc 14: 1-89.

Wirth, W. W., and F. S. Blanton. 1956. Studies in Panama Culicoides (Diptera: Heleidae). VI: the hylas group of the subgenus Hoffmania. J. Wash. Acad. Sci. 46: 95-99.

Wirth, W. W., A. L. Dyce, and G. R. Spinelli. 1988. An atlas of wing photographs, with a summary of the numerical characters of the Neotropical species of Culicoides (Diptera: Ceratopogonidae). Contrib. Amer. Entomol. Inst. 25: 1-72. 